OPEN ACCESS

Edited by:

Mercedes González-Wangüemert,

University of Algarve, Portugal

Reviewed by:

Oscar Sosa-Nishizaki,

Center for Scientific Research and Higher Education in Ensenada

(C/CESE), Mexico

Elena Barcala Bellod,

Spanish Institute of Oceanography

(IEO), Spain

Steven W. Purcell,

Southern Cross University, Australia

*Correspondence:

Jorge Ramírez-González jorge.ramirez.glez@gmail.com; jorge.ramirez@fcdarwin.org.ec

Specialty section

This article was submitted to Marine Fisheries, Aquaculture and Living Resources,

a section of the journal

Frontiers in Marine Science

Received: 21 April 2020 Accepted: 09 October 2020 Published: 30 October 2020

Citation: Ramírez-González J, Moity N, Andrade-Vera S and Reyes H (2020)

Overexploitation and More Than a Decade of Failed Management

Leads to No Recovery of the Galápagos Sea Cucumber Fishery.

Front. Mar. Sci. 7:554314. doi: 10.3389/fmars.2020.554314

\section{Overexploitation and More Than a Decade of Failed Management Leads to No Recovery of the Galápagos Sea Cucumber Fishery}

\author{
Jorge Ramírez-González ${ }^{1 *}$, Nicolas Moity ${ }^{1}$, Solange Andrade-Vera ${ }^{1}$ and Harry Reyes ${ }^{2}$ \\ ${ }^{1}$ Charles Darwin Research Station, Charles Darwin Foundation, Puerto Ayora, Ecuador, ${ }^{2}$ Conservation and Use of Marine \\ Ecosystems Process, Galápagos National Park Directorate, Puerto Ayora, Ecuador
}

Isostichopus fuscus is the most important sea cucumber species exploited in the Eastern Tropical Pacific. It was the most important fishery in the Galápagos in the early 2000s until overfishing led to its collapse and a 5-year total fishing ban was established (2016-2021) to try to recover it. The management of I. fuscus in the Galápagos has always considered the population density as an indicator for decision-making. The objective of this study is to review the density as an indicator of the population status of I. fuscus using a stock-production model incorporating covariates methodology. For the first time, population and fishing parameters $(K, r$, and $q)$, reference points ( $M S Y, B_{M S Y}$, $F_{M S Y}$, and $\left.D_{M S Y}\right)$ and indicators $\left(B / B_{M S Y}\right.$ and $\left.F / F_{M S Y}\right)$ were estimated for I. fuscus. The results indicate that the management measures have not prevented the overexploitation of this species for more than a decade. The goal of the I. fuscus management plan in the Galápagos, i.e., the recovering the fishery in a non-fishing scenario, will not be met by 2030. To accomplish its recovery six recommendations are proposed, including to extend the total ban of the fishery and to change the current management indicators to $B / B_{M S Y}$ and $F / F_{M S Y}$. This study evidences that management measures taken with little scientific basis can have a pervasive effect on natural resources.

\footnotetext{
Keywords: Isostichopus fuscus, overexploitation, small-scale fishery, management, Galápagos, maximum sustainable yield, reference points
}

\section{INTRODUCTION}

Sea cucumbers have a high demand and value in markets of Asia because they are considered a food delicacy and have an important cultural in traditional medicine (Purcell, 2010; Fabinyi, 2012; To and Shea, 2012; Purcell et al., 2018). At the same time, sea cucumbers are very vulnerable to overexploitation due to the ease of capture that contributes to accelerated exploitation, increased demand, inefficient fisheries management, low recruitment, high longevity and density-dependence reproduction (Kinch et al., 2008; Purcell, 2010). Several countries and territories have established moratoria on sea cucumber fishing due to population declines (e.g., Australia, Mauritius, Mayotte, Papua New Guinea, Salomon Islands, Venezuela, and Ecuador including Galápagos) (Purcell et al., 2012; Dirección del Parque Nacional Galápagos et al., 2016). The International Union for Conservation of Nature has classified nine species of sea cucumbers as vulnerable and seven as endangered, the latter includes Isostichopus fuscus (IUCN, 2020). The Convention on International Trade in Endangered 
Species has three species of sea cucumbers listed on Appendix II and the only species listed on Appendix III is I. fuscus (CITES, 2020).

It is common for density-based reference points to be used to determine the population status of sea cucumbers. Purcell et al. (2009) considered reference points for commercial sea cucumbers in New Caledonia in a tentative and subjective way. These authors considered densities $<1$ sea cucumber/100 $\mathrm{m}^{2}$ as low and densities $<0.3$ sea cucumber $/ 100 \mathrm{~m}^{2}$ to be at, or near, a critical level at which populations will fail to repopulate effectively. The authors suggested to interpret these reference points in a meta-population dynamics context and that the suggested thresholds will be more realistic for some species than others.

The Secretariat Pacific Community developed reference densities for 18 species of sea cucumbers species of the centralwestern Pacific Ocean (Pakoa et al., 2014a). These densities are an average of the $25 \%$ of the highest densities recorded for each species from 2002 to 2012 in 91 sites of 17 countries. These reference densities were proposed as baseline to check for healthy abundances in a "rule of thumb" way in absence of site-specific density reference for sea cucumbers (Pakoa et al., 2014a).

Pinca et al. (2010) proposed to use densities observed to infer at which one a stock is considered depleted or in healthy condition. These authors suggested reference points for Holothuria whitmaei, Bohadschia argus, and Holothuria atra using their densities collected in Pacific Island countries and territories. In Seychelles, Aumeeruddy et al. (2005) used densities to determine the status (i.e., underexploited, unexploited, exploited, and overexploited) of more than 20 species of sea cucumbers.

In few monospecific sea cucumber fisheries, density is used as an indicator to open or close fisheries. Examples are Cuba for Isostichopus badionotus (Hernandez-Betancourt et al., 2018), Canada for Parastichopus californicus (Fisheries and Oceans Canada, 2019) and Galápagos, Ecuador for I. fuscus.

Surplus production models have been applied to know the population status of three species of sea cucumbers previously, in addition to $I$. fuscus in the present study. Hernandez-Betancourt et al. (2018) applied the dynamic surplus production model of Schaefer to assess the population of I. badionotus in the southern coast of Camagüey, Cuba. Koike (2017) used the Pella-Tomlinson surplus production model to assess the population of Holothuria fuscogilva in Seychelles. Hajas et al. (2011) developed a surplus production model and compared it with the Schaefer model for Parastichopus californicus in British Columbia, Canada. Bradbury et al. (1996, 1998) used Schaefer model and Woodby et al. (1993) applied Caddy surplus production model for P. californicus in Washington and Alaska, United States, respectively.

I. fuscus is the main commercially exploited sea cucumber in four countries of the Eastern Tropical Pacific: Mexico, Panama, Peru and Ecuador (Toral-Granda, 2008). Exploitation of I. fuscus in mainland Ecuador began in 1988 to supply Asian markets but soon decayed due to a collapse of the population from overfishing. Since 1992, there is a fishing ban in mainland Ecuador that prompted a migration of the activity to the Galápagos Islands (Carranza and Andrade, 1996).
In the Galápagos Marine Reserve (GMR), the I. fuscus fishery was the most important at the beginning of this century until it was considered overexploited in the mid2000s (Dirección del Parque Nacional Galápagos, 2015). In 2016, a total closure for 5 years was established for this fishery in order to achieve its recovery in the GMR (Dirección del Parque Nacional Galápagos et al., 2016).

The management of the I. fuscus fishery in the GMR has always considered the density of its population as an indicator on which to decide to open or close the fishery since it has been assumed as a representation of the population status. In 2002, the GMR co-management system approved two reference points on which to decide the opening of the I. fuscus fishery each year: (1) 40 sea cucumbers $/ 100 \mathrm{~m}^{2}$; (2) That the catch per unit effort (CPUE) does not decrease for three consecutive years in three quarters of the macro-zones into which the I. fuscus fishing area in the GMR was divided ${ }^{1}$.

In 2008, these indicators were changed into a traffic light system in which the density in the west of Isabela Island indicates the population status of I. fuscus in the GMR. A density greater than or equal to 21 sea cucumbers $/ 100 \mathrm{~m}^{2}$ indicates a healthy population; if the density is equal to 11 or less than 20 sea cucumbers $/ 100 \mathrm{~m}^{2}$ the population is in a recovery status and; if it is less than 11 sea cucumbers $/ 100 \mathrm{~m}^{2}$ it is in a critical status. This system contains decision rules where, if the I. fuscus population is healthy or recovering, the fishery opens with 60 days of fishing, a total allowed catch (TAC) and closure of critical areas (e.g., recruitment areas or areas with low densities). If the population has a critical status, the fishery remains closed (Reyes et al., 2008). This system is currently in place.

Given this historical framework, the objective of this study is to use a surplus production model to review the density as an indicator of the population status of I. fuscus and its use as a decision rule for the management of the fishery of this species in the Galápagos. This study is the first to estimate population and fishery parameters of I. fuscus, which will contribute to the knowledge and management of this species in the Tropical Eastern Pacific region.

This study is the second stage of a reengineering of the management of this resource in the Galápagos. The first stage was to estimate the age and growth, to update the total mortality and the fishing and habitat area of this species in the GMR in order to propose a change in the methodology to estimate the TAC. In fact, Ramírez-González et al. (2020) recommended the use of a dynamic surplus production model to estimate several reference points for I. fuscus in the GMR. The third stage will be to carry out spatially explicit analyses of the population of I. fuscus throughout the GMR and to determine the implications for its fishery management. This reengineering has the ultimate goal to bring scientific inputs to the GMR co-management system, before 2021, when negotiations to open or keep the sea cucumber fishery closed will be back on the table and decisions on the

\footnotetext{
${ }^{1}$ Resolución No. 003-2002 (Autoridad Interinstitucional de Manejo de la Reserva Marina de Galápagos) Art. 12.
} 
management of this fishery will be taken ${ }^{2}$, especially under the new scenario of the recent economic crisis due the COVID19 pandemic.

\section{MATERIALS AND METHODS}

\section{Study Area}

The GMR is located $1,240 \mathrm{~km}$ to the west of Guayaquil city, Ecuador and has its geographical center at $96^{\circ} 46^{\prime} \mathrm{W}$ and $0^{\circ} 05^{\prime} \mathrm{S}$. The reserve covers the entire marine area within 40 nautical miles measured from the baselines of the Galápagos Archipelago and its inland waters. It comprises a total area of $\sim 138,000 \mathrm{~km}^{2}$ (Figure 1; Dirección del Parque Nacional Galápagos, 2014).

The GMR is a marine protected area of multiple permitted uses, including small-scale fishing, tourism, research and conservation. These uses were spatially restricted to areas defined by a coastal zoning from 2000 to 2015, where the no take zones covered $1 \%$ of the GMR total area and $77 \%$ of its coast (Heylings et al., 2002; Moity, 2018a). In 2016, new zoning was established to include also open waters of the GMR, where the no take zones cover $32 \%$ of the GMR's total area (Ministerio del Ambiente, 2016).

Edgar et al. (2004) divided the GMR in the following five bioregions: Far northern, Northern, Western, Elizabeth and Central-southeastern (Figure 1). Each bioregion was defined on the basis of multivariate analysis of shallow subtidal rocky reef fish and macroinvertebrate communities. Each bioregion is characterized by mix of species derived from Indo-Pacific, Panamic, Peruvian, and endemic source areas.

\section{Data Sources}

I. fuscus density data for the 2000 to 2007 time frame was obtained from the Research and Fishing Participatory Monitoring Program database of the Charles Darwin Foundation, Galápagos National Park Directorate (GNPD) and the fishing sector of Galápagos. For the 2008-2019 time frame, the density data was obtained from the Sea Cucumber Population Monitoring Program database of the GNPD and the fishing sector of Galápagos. From 1999 to 2008 there were pre and post fishing season monitoring, while since 2008 only pre fishing season monitoring were carried out. For this study, only pre fishing season monitoring data were used.

Both monitoring programs were designed to estimate the exploitable abundance of $I$. fuscus and were carried out in the fishing and habitat area of I. fuscus in the GMR (Figure 1). To estimate density, all the sea cucumbers inside a circular plot of $100 \mathrm{~m}^{2}$ (radius of $5.64 \mathrm{~m}$ ) were counted. In total, 6,887 plots were settled between $<1$ and $38 \mathrm{~m}$ depth (11.7 m mean; $6.1 \mathrm{~m} \mathrm{SD}$ ) (Supplementary Table 1).

Fishing data of I. fuscus from the GNPD datasets for years 1999 to 2005, 2011, and 2015 were also used. Datasets for years 2007 and 2008 were excluded because they did not contain enough variables for the CPUE standardization (see section "I. fuscus Standardized CPUE"). For the rest of the years there were no

\footnotetext{
${ }^{2}$ Dirección del Parque Nacional Galápagos. Meeting minute, June 5, 2020.
}

fishing data due to the sea cucumber fishing ban. For this study, only fishing data from landing ports monitoring were used because sampling with captain's logbooks and onboard observers where conducted only in 2000-2001 and 1999-2005, respectively.

The landing ports monitoring consisted of persons who recorded the date and counted all the sea cucumbers from each arriving fishing vessel. The captain of each fishing vessel was also interviewed about the number of fishing days, vessel type, whether the vessel was towed to a mother boat, the number of divers, the fishing site, the type of diving and the fishing depth (in meters). For this study, only hookah diving as the type of diving was used because scuba diving and free diving had only 41 observations in total (vs. 11,438 observations for hookah diving).

\section{Indicators and Reference Points}

A stock-production model incorporating covariates (ASPIC) methodology (Prager, 1994, 2016) was employed to estimate indicators and reference points for I. fuscus fishery in the Galápagos. ASPIC fits in a non-equilibrium way the following surplus-production models: the logistic production model of Schaefer $(1954,1957)$ and Pella (1967); the generalized model of Pella and Tomlinson (1969) as reparametrized by Fletcher (1978) and; the Fox exponential yield model (Fox, 1970). The fit in a non-equilibrium way is important for sea cucumbers because it has been documented that several species do not have an annual recruitment, which violates the equilibrium assumption (Purcell, 2010).

ASPIC's outputs includes the following estimations with confidence intervals: carrying capacity $(K)$, catchability coefficient $(q)$, maximum sustainable yield (MSY), fishing mortality rate at MSY $\left(F_{M S Y}\right)$, and abundance at MSY $\left(B_{M S Y}\right)$. ASPIC also estimates projections of population abundance and fishing mortality rates.

Three time-series from 2000 to 2019 were created as inputs for ASPIC methodology: 1) I. fuscus abundance; 2) I. fuscus standardized CPUE and; 3) total catches. The latter was obtained from Dirección del Parque Nacional Galápagos (2015).

\section{I. fuscus Abundance}

The annual abundances were estimated with the following equation modified from Wolff et al. (2012b) for I. fuscus in the GMR:

$$
B_{t}=\Sigma\left(d_{t j} * A_{j}\right)
$$

Where $B_{t}$ is the abundance in number of sea cucumbers for the year $t, d_{t j}$ is the median of the density given in sea cucumbers/100 $\mathrm{m}^{2}$ for the year $t$ and monitoring zone $j$ (obtained from the population monitoring programs) and $A_{j}$ is the fishing and habitat area of $I$. fuscus in the monitoring zone $j$. Because, in every case, the densities did not have a normal distribution (ShapiroWilk; $p<0.001$ ), and were skewed toward zero, the median was used as a representative measure of central tendency of $d_{t j}$. In 2012, no density sampling was done on the islands of San Cristóbal and Española, and in 2014, no density sampling was done in the Elizabeth bioregion; so the density values for these years and monitoring zones were assumed by averaging 


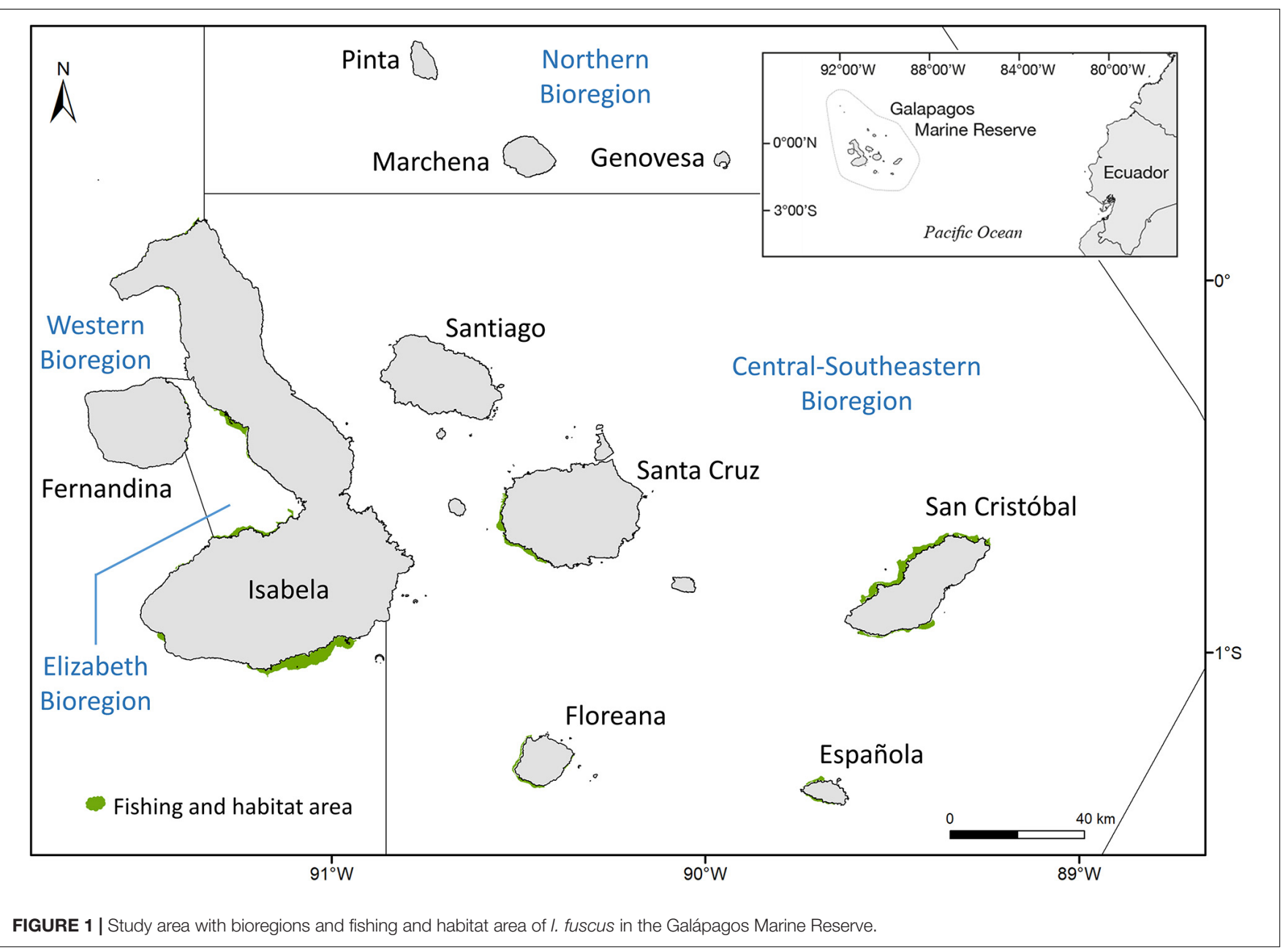

the previous year's density value with the following year's density value (Supplementary Table 2).

Since it is known that sea cucumbers can have spatial density patterns that depend on different environmental characteristics (Domíngez-Godino and González-Wangüemert, 2020), a Kruskal-Wallis test with 95\% confidence was performed to see differences between the densities across the different monitoring zones of $I$. fuscus. Each monitoring site was assigned to a bioregion on the basis of spatial analysis using Moity (2019) bioregion dataset in ArcGIS 10.6.1. There were statistical differences between the three bioregions in which the monitoring programs were carried out (i.e., Western, Elizabeth and Central-southeastern). Because the Central-southeastern bioregion included more sampling zones in a wider spatial range than the other two bioregions, another Kruskal-Wallis test was conducted to see differences between the islands within this bioregion. There were statistical differences between Española Island and the rest of islands and between San Cristóbal island and the rest of the islands (Supplementary Table 3). With these results, the following zones $\left(A_{j}\right)$ were determined for the annual abundance estimate: Western, Elizabeth, Central-SE Santa Cruz-Floreana, Central-SE San Cristóbal and Central-SE Española (Figure 1). The fishing and habitat areas of I. fuscus of each monitoring zone were calculated using the methodology of Ramírez-González et al. (2020) and the dataset of Moity and Ramírez-González (2019) (Supplementary Table 3).

\section{I. fuscus Standardized CPUE}

The CPUE was defined as the number of sea cucumbers caught per diver per day. Zero values of CPUE $(n=6)$ and CPUE in the Northern bioregion $(n=1)$ were not used for the standardization. A Linear Multiple Regression model was used to standardize the CPUE for each year. Prior the CPUE standardization, Generalized Variance-Inflated Factor (GVIF) tests were conducted to select the covariates that were not correlated. The covariates tested were year, landing port (Puerto Ayora, Puerto Baquerizo Moreno, Puerto Villamil), month, towed (yes, no), vessel type (fiberglass, wood), bioregion of fishing site (according to Edgar et al., 2004; Moity, 2019) and fishing depth. According to Zuur et al. (2010) covariates with GVIF values $>3$ are correlated. We sequentially dropped collinear covariates following Zuur et al. (2010)'s criteria until all covariates had GVIF values $<3$. The final explanatory covariates chosen were year as factor, towed as factor, bioregion as factor (Western and Elizabeth bioregions were pooled) and fishing depth as continuous (Supplementary Table 4). The tests were conducted 

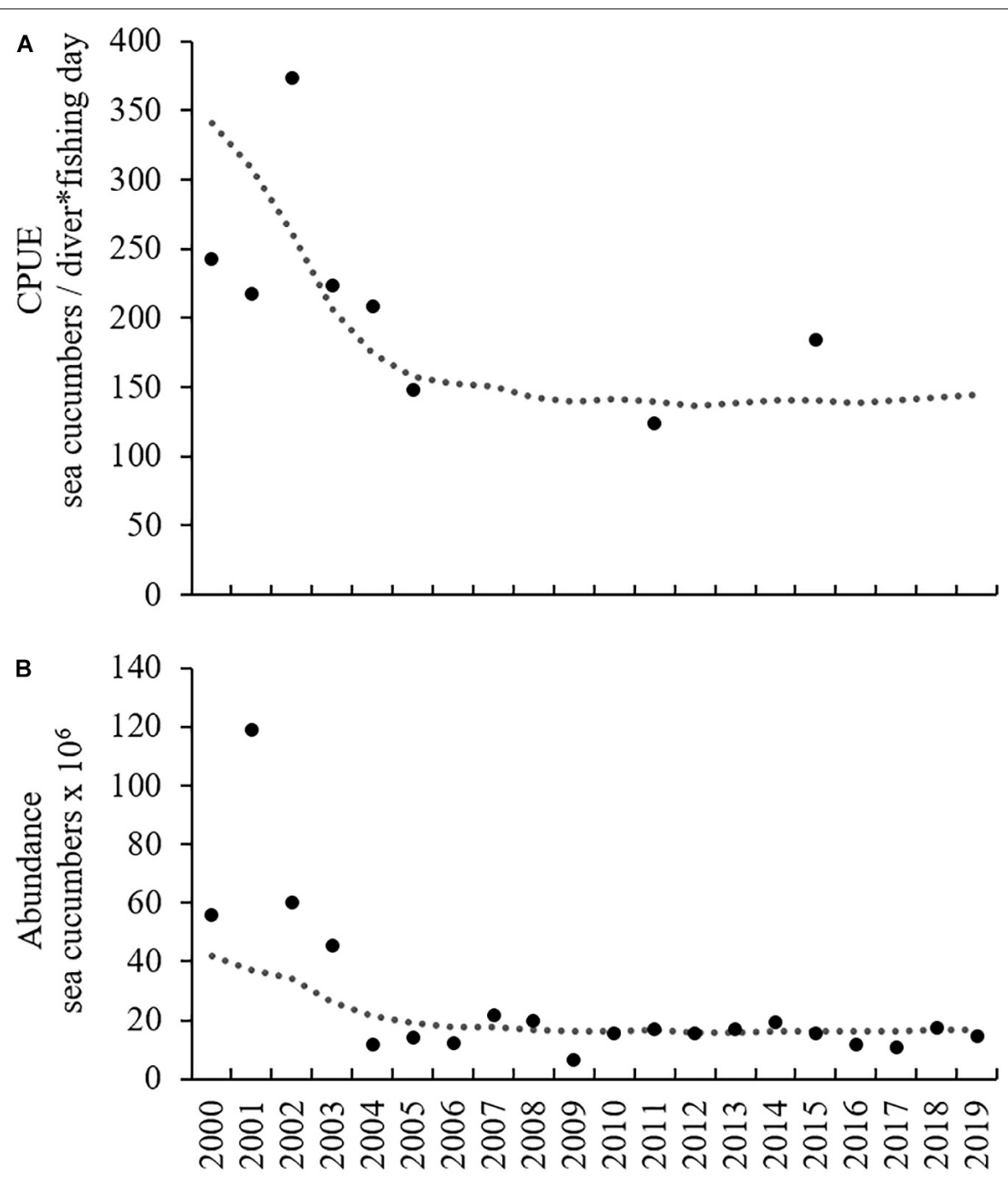

- Observations ...... Models

FIGURE 2 | Goodness-of-fit of ASPIC models of abundance (A) and CPUE (B) of I. fuscus in the GMR.

using the vif function of the car package (Fox and Weisberg, 2019) from $R$ (R Core Team, 2017) with RStudio software (RStudio Team, 2020).

The CPUE data was log-normalized. Normality of log-CPUE was tested visually by means of Q-Q plots and accumulative density plot (Supplementary Figure 1). Q-Q plots revealed deviance from normality, however, we kept using log-CPUE in the model since there are known issues with null-hypothesis significance test for non-normality with very large sample sizes, as it is the case in this study $(n=11,431)$. See Supplementary Material for the model validation.

\section{ASPIC Fits}

The ASPIC 7 software (Prager, 1994, 2016) in BOT program mode was used to fit de time series with the logistic Schaefer model and to compute bootstrapped confidence intervals. The estimation method chosen was maximum a posteriori (i.e., a form of penalized likelihood using Bayesian priors) with 20,000 Monte Carlo searches. We performed 1,000 bootstraps with $95 \%$ confidence intervals as recommended by Prager (2016). The seed values of abundance at the start of the first year, $K$ ratio $\left(B_{1} / K\right), M S Y, F_{M S Y}$ and $q$ were $0.5,5.27 \times 10^{6}, 0.058$ and $6 \times 10^{-6}$, respectively. $B_{1} / K$ was determined as Prager (2016) suggests. $M S Y, F_{M S Y}$, and $q$ were determined with preliminary maximum likelihood fits of the model (See Supplementary Material for ASPIC 7 script). The contrast index and the nearness index were used to determine the goodness of fit of the model. The contrast index is the mean of $B$ coverage proportions $>$ and $<B_{M S Y}$, where a value $=0.5$ is a good fit and value $=1$ the best fit (Prager, 2011). The nearness index is the proportional closeness of any $B$ to $B_{M S Y}$, it takes values from 0 to 1 , where 1 is the best fit (Prager, 1994, 2016).

With the estimations of $M S Y, K$, and $B_{M S Y}$, the intrinsic rate of population growth $(r)$ was calculated with $r=M S Y /(K / 4)$ and the 
TABLE 1 | Parameters and reference points estimated for I. fuscus in the GMR.

\begin{tabular}{lcccc}
\hline & Unit & Estimate & C.I. low & C.I. up \\
\hline Parameters & & & & \\
$B 1 / K$ & Ratio & 0.89 & 0.86 & 0.90 \\
$K$ & Sea cucumbers & $4.67 \times 10^{7}$ & $4.49 \times 10^{7}$ & $5.26 \times 10^{7}$ \\
$q$ & Coefficient & $8.66 \times 10^{-6}$ & $7.00 \times 10^{-6}$ & $9.76 \times 10^{-6}$ \\
$r$ & Rate & 0.020 & 0.010 & 0.024 \\
Reference points & & & & \\
$M S Y$ & Sea cucumbers & $2.31 \times 10^{5}$ & $1.16 \times 10^{5}$ & $3.13 \times 10^{6}$ \\
$B_{M S Y}$ & Sea cucumbers & $2.34 \times 10^{7}$ & $2.25 \times 10^{7}$ & $2.63 \times 10^{7}$ \\
$F_{M S Y}$ & Rate & 0.010 & 0.005 & 0.01 \\
$D_{M S Y}$ & Sea cucumbers/100 $\mathrm{m}^{2}$ & 0.57 & 0.55 & 0.64 \\
\hline
\end{tabular}

$\mathrm{Cl}=95 \%$ confidence intervals.

density at $M S Y\left(D_{M S Y}\right)$ with $D_{M S Y}=B_{M S Y} / A_{\text {tot }} / 10,000$. Where $A_{\text {tot }}$ is the sum of the area of suitable habitat for $I$. fuscus in the GMR calculated in $4,102 \mathrm{~km}^{2}$ by Moity (2018b), it is assumed that this species has a single population in the GMR.

Time series of the $F / F_{M S Y}$ and $B / B_{M S Y}$ indicators for I. fuscus in the GMR were made, where values of $F / F_{M S Y}>1$ and $B / B_{M S Y}<1$ refer to an overexploited population. 10-year projection of $B / B_{M S Y}$ under a non-fishing scenario of $I$. fuscus in the GMR was also made using the ASPIC 7 software extension ASPICP 5 (see Supplementary Material for ASPICP 5 script).

\section{RESULTS}

I. fuscus density range of all the plots analyzed was 0-860 sea cucumbers/100 $\mathrm{m}^{2}$ from 2000 to 2019 (5 median; 2 25thpercentile; 9 75th-percentile). The CPUE range was 1-9,320 sea cucumbers/diver per fishing day (256 mean; 309 SD). Supplementary Table 1 shows the 2000-2019 time series of abundance estimated, CPUE standardized and total catches recorded of $I$. fuscus in the GMR.

The CPUE model fitted well to the CPUE standardized, meanwhile the abundance model fitted well as of 2003 (Figure 2). Schaefer's model had a good fit in relation to $B$ and $B_{M S Y}$, the contrast index was 0.6 and the nearness index was 1 . Table 1 shows the estimates of the population parameters and reference points of $I$. fuscus in the GMR.

According to the $B / B_{M S Y}$ indicator, I. fuscus has been overexploited since 2004 and the value of $F / F_{M S Y}$ has always been greater than 1 . The 10 -year projection of the $B / B_{M S Y}$ indicator under a non-fishing scenario estimated that the I. fuscus population will not reach the $B_{M S Y}$ in 2030 (Figure 3).

\section{DISCUSSION}

The use of density as reference point for the management of the I. fuscus fishery in the GMR has failed because it did not prevent the overexploitation of this species. The density estimates as an indicator have been based on observations without further verification and have not considered the spatial dynamics of this species. The density of 40 sea cucumbers $/ 100 \mathrm{~m}^{2}$ proposed as a "sustainability coefficient" of I. fuscus in the GMR in 2002, was based on observations where the reproductive aggregations of this species had at least this density ${ }^{3}$. Castrejón et al. (2007) said that this density was poorly estimated, since, until then, the average density of this species was never higher than 35 sea cucumbers $/ 100 \mathrm{~m}^{2}$ in the GMR. They noted also that it was not clear whether this reference point referred to the total fishing area or to a specific fishing area. Moreover, it has not been proven whether 40 cucumbers $/ 100 \mathrm{~m}^{2}$ is the optimal density for the reproduction of $I$. fuscus in the GMR.

The density of 11 cucumbers $/ 100 \mathrm{~m}^{2}$ proposed as indicator of critical status of I. fuscus population in the GMR, was based on the observation that the lowest catches of this species occurred with densities lower than this value on the west of Isabela Island (Reyes et al., 2008). No rigorous analysis has been done to see the relation between catches and density of this species. Furthermore, as demonstrated in this study and in Glockner-Fagetti and Benítez-Villalobos (2016), I. fuscus has a differentiated spatial abundance, so the density of an area (e.g., west of Isabela Island) does not represent the density throughout its distribution range. Therefore, it is not recommendable to determine a single density value as an indicator of population status of I. fuscus in the GMR.

The $D_{M S Y}$ estimated in this study ( 0.57 sea cucumbers $/ 100$ $\left.\mathrm{m}^{2}\right)$ is quite close to the estimated for I. badoinotus in Cuba (0.45 sea cucumbers $/ 100 \mathrm{~m}^{2}$; Hernandez-Betancourt et al., 2018). However, it is much higher than the $D_{M S Y}$ estimated for H. fuscogilva in Seychelles (0.002-0.005 sea cucumbers $/ 100 \mathrm{~m}^{2}$; Koike, 2017), although it is a much larger species (Purcell et al., 2012) that occurs naturally at lower densities (Pinca et al., 2010). The $D_{M S Y}$ of $I$. badoinotus and $H$. fuscogilva are probably underestimated because the authors assumed that the entire study area is suitable habitat for each respective species. Our $D_{M S Y}$ is probably also biased since the habitat area of I. fuscus was modeled with observations mostly in the south of the Northern bioregion and with a still not very accurate bathymetry for the GMR (Moity, 2018b).

Our $D_{M S Y}$ is in line with the density-based reference points suggested by Purcell et al. (2009) for sea cucumbers in New Caledonia, in the sense that less than 0.3 sea cucumber $/ 100 \mathrm{~m}^{2}$ indicates a critical status. Of the 18 species with regional reference densities of the Secretariat of the Pacific Community, five exceed our $\mathrm{D}_{M S Y}$ : Holothuria atra (56 sea cucumbers/100 $\mathrm{m}^{2}$ ), Stichopus chloronotus (35 sea cucumbers $/ 100 \mathrm{~m}^{2}$ ), Bohadischia similis (14 sea cucumbers/100 $\mathrm{m}^{2}$ ) Holothuria coluber (11 sea cucumbers/100 $\mathrm{m}^{2}$ ) and Holothuria scabra (0.7 sea cucumbers/100 $\mathrm{m}^{2}$ ) (Pakoa et al., 2014a). It appears that I. fuscus requires relatively higher densities than many of tropical sea cucumber species to keep its population healthy.

I. fuscus has higher densities than those for other tropical sea cucumber species, considering the observed values. Pooling the annual densities of this study, the median density of I. fuscus per monitoring zone is nine, eight, five, four and

\footnotetext{
${ }^{3}$ Autoridad Interinstitucional de Manejo de la Reserva Marina de Galápagos. Meeting minute, April 30, 2001.
} 


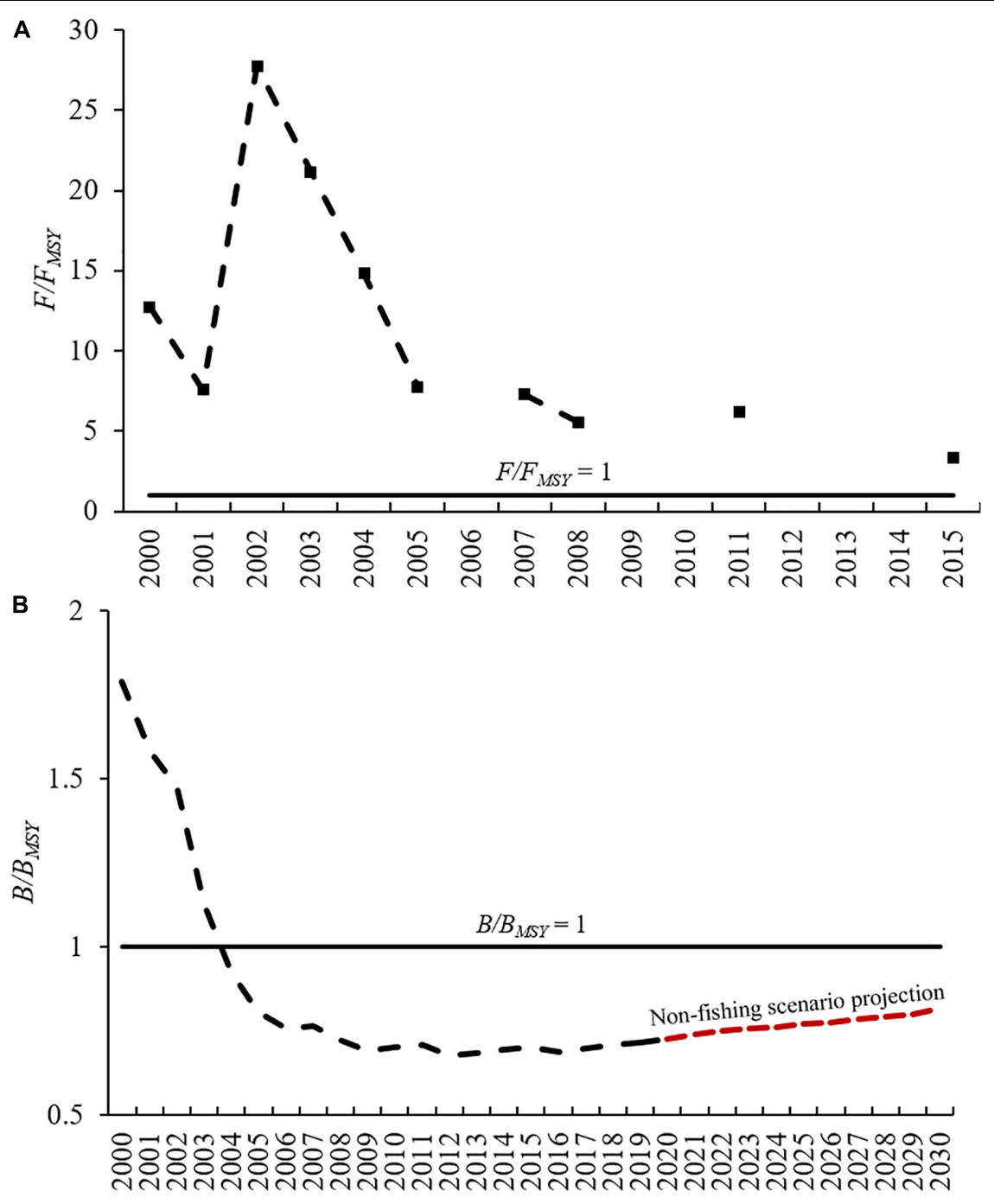

FIGURE 3 | Trajectories of $F / F_{M S Y}$ (A) and $B / B_{M S Y}$ (B) from Schaefer model for I. fuscus in the GMR.

six sea cucumbers $/ 100 \mathrm{~m}^{2}$ for Western, Elizabeth, Central-SESanta Cruz-Floreana, Central-SE-San Cristóbal, and CentralSE-Española, respectively. Of more than 25 species of tropical sea cucumbers studied in the Central Pacific (Purcell et al., 2009; Pinca et al., 2010; Pakoa et al., 2013, 2014b) and Seychelles (Aumeeruddy et al., 2005; Koike, 2017), only H. scabra, Bohadschia vitensis, Stichopus spp., Holothuria hilla and H. atra had occasionally observed densities greater than four sea cucumbers $/ 100 \mathrm{~m}^{2}$.

Observed densities of $I$. fuscus have varied with respect to its geographic distribution and time, with the highest densities recorded in its most northern (northwestern Mexico) and southern (Galápagos) distribution. In Baja California Peninsula densities of 30 sea cucumbers $/ 100 \mathrm{~m}^{2}$ of I. fuscus (FajardoLeón and Vélez, 1996), 27 sea cucumbers/100 $\mathrm{m}^{2}, 15$ sea cucumbers/100 $\mathrm{m}^{2}$ (Glockner-Fagetti et al., 2016) and 2.8 sea cucumbers/100 $\mathrm{m}^{2}$ (Reyes-Bonilla et al., 2008) have been recorded. In southwest coast of Mexico a density of 43 sea cucumbers $/ 100 \mathrm{~m}^{2}$ were recorded in 1991, years later less than one sea cucumber/100 $\mathrm{m}^{2}$ (Nuño-Hermosillo, 2003) and 1.8 sea cucumbers/100 $\mathrm{m}^{2}$ were recorded (Glockner-Fagetti and Benítez-Villalobos, 2016). In the El Pelado Marine Reserve (mainland Ecuador), a density range of less than one to three sea cucumbers $/ 100 \mathrm{~m}^{2}$ has been recorded for 2014-2015 (García, 2015). The maximum density ever observed of I. fuscus was 88 sea cucumbers $/ 100 \mathrm{~m}^{2}$ in the Western bioregion in the GMR in 2001.

It appears that I. fuscus is among the tropical sea cucumber species with the highest observed densities. Caution should be taken in interpreting these results as the density value may vary due to environmental factors, such as, ocean productivity (Reyes-Bonilla et al., 2008; Glockner-Fagetti et al., 2016), whether the population is or was subject to exploitation (HolguinQuiñones et al., 2000), and time (e.g., month or day and night; Glockner-Fagetti et al., 2016).

On the other hand, management measures related to controlling fishing mortality (e.g., TAC and fishing season) of 
I. fuscus in Galápagos did not prevent this mortality from being above the $F_{M S Y}$ during the entire study period. From 2000 to 2008, the TAC was established using averages of catches from previous years. In 2011, the TAC was implemented by estimating MSY using the Cadima formula. In 2015, the TAC was issued at the discretion of the participants in the GMR co-management system since in this year the fishery should not have opened because it did not reach the reference point (Ramírez-González et al., 2020). The latter authors discussed the lack of rigor in the estimation of TAC in the first years and in 2015, they also concluded that the use of Cadima formula is no longer appropriate because its scope is very limited. All the TACs established for the I. fuscus fishery in the Galápagos were above our MSY estimate (Dirección del Parque Nacional Galápagos, 2015).

Illegal, underreported and unregulated (IUU) fishing of I. fuscus should also be considered. Schiller et al. (2013) found that the largest annual catch of this species occurred in 1994 (2,888 tons), when the fishery was not regulated in the Galápagos. They also calculated that 3,000 tons of this species were caught illegally between 1994 and 1999 in the Galápagos. In addition, in 2000, 2003, and 2015 the established TAC was exceeded (Reyes et al., 2013a,b; Ramírez-González et al., 2020). This IUU has most likely contributed to the overexploitation of I. fuscus in the Galápagos.

The $K$ estimate of this study suggests that the I. fuscus population has suffered a strong impact in the GMR. Considering $K$ as virgin abundance and with a conservative approach (using the $K$ low confidence interval), the population of this species in 2019 was 33\% of its virgin population. Wolff et al. (2012b) assumed that the abundance of I. fuscus in 2009 was already $50 \%$ below of its virgin abundance; our estimations indicate that in 2009 the abundance was 15\% below (under a conservative approach), which is, in fact, the lowest percentage recorded during the study period.

The intrinsic growth rate estimated in this paper $(r=0.02)$ corresponds to that of a slow-growing population. We have only found two other $r$-values for sea cucumbers in the literature, in both cases our $r$-value is much lower than Cisneros-Mata (2016) for I. fuscus in Mexico ( $r=0.5)$ and Hernandez-Betancourt et al. (2018) for I. badionotus in Cuba $(r=0.129)$. The difference with Cisneros-Mata (2016) is most likely, due to that they assumed the $r$-value from ecological and biological information on the species. The difference with Hernandez-Betancourt et al. (2018) could be due to the fact that the $r$-value of I. badionotus was estimated with a non-overexploited population and our $r$-value corresponds to an overexploited population. One thing that stands out is that, to our knowledge, this is the first time the population parameters of I. fuscus are estimated.

The impact of overexploitation led to the fact that, according to our 10-year projection, I. fuscus will not reach the MSY level in 2030 under a non-fishing scenario in the GMR. There are examples of sea cucumbers with slow recovery after a moratorium. Holothuria whitmaei still had depleted levels after a 7-year moratorium in Tonga (Friedman et al., 2011). H. scabra had a slow recovery after 6-year moratorium in Warrior Reef, Australia (Kinch et al., 2008).
However, there is an increasing trend in the I. fuscus population from 2016 onwards in the GMR. This implies that the impact of overexploitation did not exceed density thresholds where the reproductive potential of I. fuscus fails to recovery its population. The lowest median densities per monitoring zone were observed in $2009\left(1-4\right.$ sea cucumbers/100 $\left.\mathrm{m}^{2}\right)$. Therefore, probably this range is above the tipping point where I. fuscus can no longer recover in the GMR. This considering that the sea cucumbers are gonochoric (i.e., separate sexes) and have low mobility, which make them highly dependent on its density (Lovatelli et al., 2004).

The no recovery of I. fuscus in the short-term in the Galápagos is important because currently fishers and part of the local population have considered this resource as an alternative for economic reactivation in the face of the negative impacts of the COVID-19 pandemic. The results of this study contribute to realign the expectations about I. fuscus in the Galápagos and to start thinking that this resource is not going to be available in the long-term.

It is important to account for the climate variability as a factor that may have influenced our results. The higher abundances of the first years of the study (2000-2001) may have been influenced by the 1998-1999 strong La Niña event, being one of the strongest after the 1988-1989 La Niña in the GMR (National Oceanic and Atmospheric Administration, 2013). The high productivity associated with such events (Palacios, 2004), especially on the west of Isabela Island and in Fernandina Island, where major fishing grounds occur, could have yielded a peak in I. fuscus reproduction and abundance, in the following years. There are studies that have demonstrated influence of climate variability on I. fuscus population in the west of the GMR (Hearn et al., 2005; Wolff et al., 2012a). This could result in a biased baseline in the model used in this study.

Absolut values of the parameters and reference points estimated should be taken with caution. Prager (2016) says that ASPIC estimate more precisely $M S Y, B / B_{M S Y}$ and $F / F_{M S Y}$ and less precisely absolute levels of $B, F$, and $q$. He also mentions that $B / B_{M S Y}$ and $F / F_{M S Y}$ explain better the condition of the population, because in normalization, the estimate of $q$ cancels out. Nevertheless, even considering the biases, there is evidence that the I. fuscus population in the Galápagos is overexploited and without a recovery to MSY levels in the short-term.

The biological objective for the I. fuscus fishery established in the Five-Year Fishing Calendar 2016-2021 (Fishing management plan of the GMR) states as "to recover the abundance of the sea cucumber populations ensuring a healthy population structure" (Dirección del Parque Nacional Galápagos et al., 2016). Our results show that the 5-year closure of this fishery will not meet this objective.

Finally, there are still research gaps to be addressed for the correct management of this sea cucumber species in the GMR. All the analyses have been done in the habitat and fishing area of I. fuscus, however, the species is widely distributed in the GMR (Ramírez-González and Reyes, 2018; Moity, 2018b) although it is not captured in the entire Reserve. The total abundance of I. fuscus in the GMR and the population spatial-temporal 
dynamics are unknown. It may be possible that the population of this species in non-fishing areas contribute to the recovery of the ones in the fishing areas due to a spill-over effect. In addition, we still do not know the potential impacts of climate change and climate variability on the I. fuscus population in the GMR. The impacts that the overexploitation of $I$. fuscus is causing on the ecosystems of the GMR are currently unknown. It is very important to conduct economic and social science research on this resource in the GMR and, to link it to biological and ecological research to understand the drivers resulting in its overexploitation.

\section{Recommendations for the Management of $I$. fuscus Fishery in the GMR}

The findings of this study suggest that the $I$. fuscus population is still not recovered from overfishing and the fishery should remain closed. Particularly, we recommend the following:

1. To use the trend in abundance of $I$. fuscus, considering the $B_{M S Y}$ as limit reference point. The limit reference points are values that indicate an undesirable status of the fishery and should be avoided (Caddy and Mahon, 1995).

2. To open the I. fuscus fishery when its abundance in the GMR reach a positive trend above the $B_{M S Y}$ value.

3. To restock I. fuscus in the GMR by collecting adult sea cucumbers present in the same area of a monitoring site and release them in the nearest no-take zone, according to GMR zoning. This intervention could be more costeffective than a captive-release program (Bell et al., 2008), but would need consideration of the legal, administrative and cost issues and to carry out control and surveillance in the no-take zones to ensure the success of this action.

4. To strengthen control and surveillance to reduce IUU fishing of sea cucumbers in the GMR to zero.

5. When the I. fuscus fishery opens in the GMR, to establish the TAC by multiplying the low confidence of interval of the $\mathrm{F}_{M S Y}$ by the $B_{M S Y}$.

6. To continue with the Sea Cucumber Population Monitoring Program of the GNPD and fishing sector of Galápagos. It is important to validate with empirical data the 10 -years projection made in this study.

\section{CONCLUSION}

This is the first time that the population parameters of I. fuscus are estimated using a surplus production model. Under the categorization of Dowling et al. (2013), this fishery improved its data use and went from level 4 (empirical estimates of biomass based on fishery independent surveys) to level 2 (assessment of $F$ and $B$ based on fishery dependent and fishery independent data), where 0 is the maximum level.

The management of $I$. fuscus have not prevented its overexploitation for more than a decade and have lead to absence of its recovery to the MSY level in the short-term in the GMR, even under a non-fishing scenario. This study evidences the impact that taking management measures with little scientific basis can have on natural resources.

To accomplish the objective of the GMR's fishing management plan of I. fuscus recovery, it is neccesary to continue the ban of its fishery and change its current management measures, such as the current indicator and reference points.

\section{DATA AVAILABILITY STATEMENT}

The datasets for this article are not publicly available because the Galápagos National Park is the owner and administrator of the data sets and decides on their availability upon request. Requests to access the datasets should be directed to HR, hreyes@galapagos.gob.ec.

\section{AUTHOR CONTRIBUTIONS}

JR-G conceived the research idea, analyzed the data, and wrote the manuscript with inputs from NM and SA-V. HR was in charge of planning and conducting field trips, as well as collecting and storing field data. All authors contributed to the article and approved the submitted version.

\section{FUNDING}

Gordon \& Betty Moore Foundation, Grant No. 8072, financed the time of the CDF staff. Galápagos National Park Directorate financed the sea cucumber monitoring programs and time of GNPD staff.

\section{ACKNOWLEDGMENTS}

We want to thank all the staff of the Charles Darwin Foundation, GNPD and all fishers of the Galápagos who participated in the sea cucumber monitoring in the GMR since 1999 until now. As well as the Government of Ecuador, international cooperation and NGOs who have financed the sea cucumber monitoring. To the peer reviewers. Charles Darwin Foundation authors would like to thank the Gordon \& Betty Moore Foundation for funding the staff time. This study was conducted under the research permit GNPD No. PC-41-20. This publication is contribution number 2349 of the Charles Darwin Foundation for the Galápagos Islands.

\section{SUPPLEMENTARY MATERIAL}

The Supplementary Material for this article can be found online at: https://www.frontiersin.org/articles/10.3389/fmars. 2020.554314/full\#supplementary-material

Supplementary Figure $1 \mid Q-Q$ and accumulative density plots of log-CPUE of I. fuscus from 2000 to 2019 in the GMR. 
Supplementary Table 1 | Months, depth, and number of plot settled in the annual density monitoring programs, catches recorded, abundances calculated and CPUE standardized of $I$. fuscus in the GMR from 2000 to 2019.

Supplementary Table 2 | Kruskal-Wallis tests and $p$-values of the pairwise comparisons using Wilcoxon rank sum test with Holm method for densities between bioregions and between islands within Central-southeastern bioregion of the population monitoring programs of I. fuscus in the Galápagos Marine Reserve.

Supplementary Table 3 | Density medians (sea cucumbers $/ 100 \mathrm{~m}^{2}$ ) of I. fuscus for year and monitoring zone and area $\left(\mathrm{km}^{2}\right)$ calculated for each monitoring zone. *Average of previous year's density value with the following year's density.

\section{REFERENCES}

Aumeeruddy, R., Skewes, T., Dorizo, J., Carocci, F., Coeur de Lion, F., Harris, A., et al. (2005). Resource Assessment and Management of the Seychelles Sea Cucumber Fishery. Report for FAO Project No. TCP/SEY/2902. Seychelles: Seychelles Fishing Authority.

Bell, J. D., Purcell, S. W., and Nash, W. J. (2008). Restoring small-scale fisheries for tropical sea cucumbers. Ocean Coast. Manag. 51, 8-9. doi: 10.1016/j.ocecoaman. 2008.06.011

Bradbury, A., Palsson, W. A., and Pacuski, R. E. (1996). Stock assessment of the commercial sea cucumber Parastichopus californicus in the San Juan Islands, Washington State, USA. Int. J. Shellf. Res. 15, 785-786.

Bradbury, A., Palsson, W. A., and Pacuski, R. E. (1998). "Stock assessment of the sea cucumber Parastichopus californicus in Washington in Echinoderms," in Proceedings of the 9th International Echinoderm Conference, San Francisco, CA.

Caddy, J. F., and Mahon, R. (1995). Reference Points for Fisheries Management. FAO Fisheries Technical Paper, No. 347. Rome: FAO.

Carranza, C., and Andrade, M. (1996). Retrospectiva de la Pesca del Pepino de mar a Nivel Continental. Puerto Ayora: Fundación Charles Darwin para las Islas Galápagos/ORSTOM.

Castrejón, M., Hearn, A., Murillo, J. C., Lalancette, A., Reyes, H., Gaibor, N., et al. (2007). Puntos de Referencia Objetivo Para la Pesquería de Pepino de mar (Isostichopus fuscus) en la Reserva Marina de Galápagos. Puerto Ayora: Comisión Técnica Pesquera de la Junta de Manejo Participativo.

Cisneros-Mata, M. A. (2016). Some guidelines for a reform in Mexican fisheries. Ciencia Pesquera 24, 77-91.

CITES (2020). Checklist of CITES Species. Available at: https://checklist.cites.org (accessed August 17, 2020).

Dirección del Parque Nacional Galápagos, (2014). Plan de Manejo de las Áreas Protegidas de Galápagos Para el Buen Vivir. Puerto Ayora: Ministerio del Ambiente/Dirección del Parque Nacional Galápagos.

Dirección del Parque Nacional Galápagos, (2015). Evaluación de la pesquería 2015 de Pepino de mar (Isostichopus fuscus) en la Reserva Marina de Galápagos. Puerto Ayora: Dirección del Parque Nacional Galápagos.

Dirección del Parque Nacional Galápagos, Comisión Técnica Pesquera, and Sector Pesquero Artesanal de Galápagos, (2016). Calendario Pesquero Quinquenal 2016-2021. Puerto Ayora: Ministerio del Ambiente/Dirección del Parque Nacional Galápagos.

Domíngez-Godino, J. A., and González-Wangüemert, M. (2020). Habitat associations and seasonal abundance patterns of the sea cucumber Holothuria arguinensis at Ria Formosa coastal lagoon (South Portugal). Aquat. Ecol. 54, 337-354. doi: 10.1007/s10452-020-09746-0

Dowling, N. A., Dichmont, C. M., Venables, W., Smith, A. D. M., Power, D., and Galeano, D. (2013). From low- to high-value fisheries: is it possible to quantify the trade-off between management cost, risk and catch? Mar. Policy 40, 41-52. doi: 10.1016/j.marpol.2012.12.009

Edgar, G. J., Banks, S., Fariña, J. M., Calvopiña, M., and Martínez, C. (2004). Regional biogeography of shallow reef fish and macro-invertebrate communities in the Galápagos archipelago. J. Biogeogr. 31, 1107-1124. doi: 10.1111/j.1365-2699.2004.01055.x

Fabinyi, M. (2012). Historical, cultural and social perspectives on luxury seafood consumption in China. Environ. Conserv. 39, 83-92. doi: 10.4103/0972-4923. 138423
Supplementary Table 4 | General Variance-Inflation Factor results to test the multicollinearity of the variables to standardize the CPUE of I. fuscus. In gray variables eliminated due GVIF $>3$. Although the variable year had a high GVIF value, it was not eliminated because it is indispensable for producing the standardized CPUE annual series.

Supplementary Data Sheet 1 | Multiple regression validation for I. fuscus CPUE standarization.

Supplementary Data Sheet 2 | ASPIC 7 script to fit Schaefer model and compute bootstrapped confidence intervals.

Supplementary Data Sheet $\mathbf{3}$ | ASPICP 5 script to made the time series of F/F $/ F_{M S Y}$ and $B / B_{M S Y}$ and the 10 -year projection.

Fajardo-León, M. C., and Vélez, B. (1996). "Pesquería de pepino de mar," in Estudio Del Potencial Pesquero y Acuícola de Baja California Sur Volumen 1, eds M. Casas-Valdez, and G. Ponce-Díaz, (Mexico: SEMARNAP), 151-166.

Fisheries and Oceans Canada, (2019). Pacific Region Integrated Fisheries Management Plan. Sea Cucumber by Dive, October 1, 2019 to September 30, 2020. Available at: https://www.pac.dfo-mpo.gc.ca/fm-gp/mplans/seacucumber-holothurie-ifmp-pgip-sm-eng.html (accessed August 17, 2020).

Fletcher, R. I. (1978). On the restructuring of the pell-tomlinson system. Fish. Bull. $76,515-521$.

Fox, J., and Weisberg, S. (2019). An R Companion to Applied Regression, 3rd Edn, Thousand Oaks: Sage Publishing.

Fox, W. W. Jr. (1970). An exponential yield model for optimizing exploited fish populations. Trans. Am. Fish. Soc. 99, 80-88. doi: 10.1577/1548-8659(1970) $99<80$ :aesmfo $>2.0 . \mathrm{co} ; 2$

Friedman, K., Eriksson, H., Tardy, E., and Pakoa, K. (2011). Management of sea cucumbers stocks: patterns of vulnerability and recovery of sea cucumber stocks impacted by fishing. Fish Fish. 12, 75-93.doi: 10.1111/j.1467-2979.2010.00384.x

García, R. C. E. (2015). Caracterización Poblacional del Pepino de mar (Isostichopus fuscus) en seis bajos de la Reserva Marina "El Pelado", Provincia de Santa Elena Ecuador, Diciembre 2014 - Mayo 2015. BSc's thesis, Universidad Estatal Península de Santa Elena, La Libertad.

Glockner-Fagetti, A., and Benítez-Villalobos, F. (2016). Spatio-temporal variation in density and size structure of the endangered sea cucumber Isostichopus fuscus in Huatulco National Park, Mexico. Mar. Ecol. 38:e12386. doi: 10.1111/maec. 12386

Glockner-Fagetti, A., Calderon-Aguilera, L. E., and Herrero-Pérezrul, M. D. (2016). Density decrease in an exploited population of Brown sea cucumber Isostichopus fuscus in a biosphere reserve from the Baja California peninsula, Mexico. Ocean Coast. Manag. 121, 49-59. doi: 10.1016/j.ocecoaman.2015. 12.009

Hajas, W., Hand, C., Duprey, H., Lochead, J., and Deault, J. (2011). Using production models with new and developing fisheries: a case study using the sea cucumber Parastichopus californicus in British Columbia, Canada. Fish. Res. 110, 421-434. doi: 10.1016/j.fishres.2011.05.009

Hearn, A., Martinez, P., Toral-Granda, M. V., Murillo, J. C., and Polovina, J. (2005). Population dynamics of the exploited sea cucumber Isostichopus fuscus in the western Galápagos Islands, Ecuador. Fish. Oceanogr. 14, 377-385. doi: 10.1111/j.1365-2419.2005.00342.x

Hernandez-Betancourt, A., Puga, R., and Borroto Vererano, R. (2018). Conservation strategy for the sea cucumber (Isostichopus badionotus) fishery in Cuba. Bull. Mar. Sci. 94:1005. doi: 10.5343/bms.2017.1005

Heylings, P., Bensted-Smith, R., and Altamirano, M. (2002). “Zonificación e historia de la Reserva Marina de Galápagos in Reserva Marina de Galápagos," in Línea Base de la Biodiversidad, eds E. Danulat, and G. J. Edgar, (Puerto Ayora: FCD-SPNG), 10-21.

Holguin-Quiñones, O., Wright-López, H., and Solís-Marin, F. (2000). Asteroidea, Echinoidea y Holothuroidea en fondos someros de la Bahía de Loreto, Baja California Sur, México. Rev. Biol. Trop. 48, 749-757.

IUCN, (2020). The IUCN Red List of Threatened Species. Version 2020-2. Available at: https://www.iucnredlist.org (accessed August 17, 2020).

Kinch, J., Purcell, S., Uthicke, S., and Friedman, K. (2008). "Population status, fisheries and trade of sea cucumbers in the Western Central Pacific in Sea Cucumbers," in A Global Review of Fisheries and Trade. FAO Fisheries and 
Aquaculture Technical Paper 516, eds V. Toral-Granda, A. Lovatelli, and M. Vasconcellos, (Rome: FAO), 7-55.

Koike, H. (2017). Fishery Ecology of Seychelles' Sea Cucumbers Fishery. Ph. D thesis, University of Hawai'i at Mânoa, Mânoa.

Lovatelli, A., Conand, C., Purcell, S., Uthicke, S., Hamel, J., and Mercier, A. (2004). Advances in Sea Cucumber Aquaculture and Management. FAO Fisheries Technical Paper. Rome: FAO.

Ministerio del Ambiente, (2016). Acuerdo Ministerial No. 093. September 12020. Quito: Ministerio del Ambiente.

Moity, N. (2018a). Evaluation of No-Take Zones in the Galápagos Marine Reserve, Zoning Plan 2000. Front. Mar. Sci. 5:244. doi: 10.3389/fmars.2018.00244

Moity, N. (2018b). "Species distribution model for the sea-cucumber, Isostichopus fuscus," in Atlas de Galápagos, Ecuador: Especies Nativas e Invasoras, ed. F. C. Darwin, (Quito: Fundación Charles Darwin/WWF-Ecuador), 90-91.

Moity, N. (2019). Marine Bioregions for Coastal Subtidal Shallow Rocky Reef of the Galápagos Archipelago, GIS layer for Edgar et al., 2004. PANGAEA. doi: 10.1594/PANGAEA.907105

Moity, N., and Ramírez-González, J. (2019). Fishing and Habitat Area for the Sea Cucumber Isostichopus Fuscus (Ludwig, 1875) in the Galápagos Marine Reserve. PANGAEA. doi: 10.1594/PANGAEA.909403

National Oceanic and Atmospheric Administration, (2013). Historical El Niño/La Niña Episodes (1950-Present). Available at: http://www.cpc.ncep.noaa.gov/ products/analysis_monitoring/ensostuff/ensoyears.shtml (accessed April 1, 2020).

Nuño-Hermosillo, A. (2003). Ecología poblacional, ciclo reproductivo e historia de la pesquería del pepino de mar Isostichopus fuscus (Ludwig, 1875) (Echinodermata: Holothuroidea) en Baja Chamela, Jalisco, México. MSc's thesis, Universidad de Guadalajara, Guadalajara.

Pakoa, K., Friedman, K., Moore, B., Tardy, E., and Bertram, I. (2014a). Assessing Tropical Marine Invertebrates: a Manual for Pacific Island Resource Managers. Noumea: Secretariat of the Pacific Community-European Union.

Pakoa, K., Masu, R., Teri, J., Leqata, J., Tua, P., Fisk, D., et al. (2014b). Salomon Islands Sea Cucumber Resources Status and recommEndations for Management. Noumea: Secretariat of the Pacific Community-European Union.

Pakoa, K., Saladrau, W., and Watisoni, L. (2013). The Status of Sea Cucumbers Resources and Fisheries Management in Fiji. Noumea: Secretariat of the Pacific Community-European Union.

Palacios, D. M. (2004). Seasonal patterns of sea-surface temperature and ocean color around the Galápagos: regional and local influences. Deep Sea Res. Part II Top. Stud. Oceanogr. 51, 1-3. doi: 10.1016/j.dsr2.2003.08.001

Pella, J. J. (1967). A Study of Methods to Estimate the Schaefer Model Parameters with Special Reference to the Yellowfin Tuna Fishery in the Eastern Tropical Pacific Ocean. Ph. D thesis, University of Washington, Seattle.

Pella, J. J., and Tomlinson, P. K. (1969). A generalized stock production model. Bull. Inter Am. Trop. Tuna Comm. 13, 416-497.

Pinca, S., Kronen, M., Friedman, K., Magron, F., Chapman, L., Tardy, E., et al. (2010). Regional Assessment Report: Profiles and Results from Survey Work at 63 Sites Across 17 Pacific Island Countries and Territories (1 March 2002 to 31 December 2009). Noumea: Secretariat of the Pacific Community.

Prager, M. H. (1994). A suite of extensions to a nonequilibrium surplus-production model. Fish. Bull. 92, 374-389.

Prager, M. H. (2011). Modification and Extension of ASPIC Software for Enhanced Integration with the R Statistics Environment. Portland: ICCAT.

Prager, M. H. (2016). User's Guide for ASPIC Suite, Version 7: a Stock-Production Model Incorporating Covariates and Auxiliary Programs. Portland: Prager Consulting.

Purcell, S. W. (2010). Managing Sea Cucumbers Fisheries with an Ecosystem Approach. Fisheries and Aquaculture Technical Paper: 250. Rome: FAO.

Purcell, S. W., Gossuin, H., and Agudo, N. N. (2009). Status and Management of the Sea Cucumber Fishery of la Grande Terre, New Caledonia, Programme ZoNéCo. Pengang: The WorldFish Center.

Purcell, S. W., Samyn, Y., and Conand, C. (2012). Commercially Important Sea Cucumbers of the World. FAO Species Catalogue for Fishery Purposes: 6. Rome: FAO.

Purcell, S. W., Williamson, D. H., and Ngaluafe, P. (2018). Chinese market prices of beche-de-mer: Implications for fisheries and aquaculture. Mar. Policy 91, 58-65. doi: 10.1016/j.marpol.2018.02.005

R Core Team, (2017). R: A Language and Environment for Statistical Computing. Vienna: R Foundation of Statistical Computing.
Ramírez-González, J., Moity, N., Andrade-Vera, S., and Reyes, H. (2020). Estimation of age and growth and mortality parameters of the sea cucumber Isostichopus fuscus (Ludwig, 1875) and implications for the management of its fishery in the Galápagos marine reserve. Aquac. Fish. 5, 245-252. doi: 10.1016/j.aaf.2020. 01.002

Ramírez-González, J., and Reyes, H. (2018). "Pepino de mar in Atlas de Galápagos”, in Ecuador: Especies Nativas e Invasoras, eds Fundación Charles Darwin and WWF-Ecuador (Quito: Fundación Charles Darwin/WWF-Ecuador), 90-91.

Reyes, H., Angulo, O., and Ramírez, J. (2013a). Monitoreo Poblacional de Pepino de mar (Isostichopus fuscus) en la Reserva Marina de Galápagos, año 2013. Puerto Ayora: Comisión Técnica Pesquera de la Junta de Manejo Participativo.

Reyes, H., Ramírez, J., and Schuhbauer, A. (2013b). Evaluation of the Sea Cucumber Fishery in the Galápagos Marine Reserve. Puerto Ayora: GNPS/GCREG/CDF/GC.

Reyes, H., Murillo, J. C., Espinoza, E., García, L., Castrejón, M., and Wolff, M. (2008). Evaluación de los Objetivos de Manejo y Puntos de Referencia Para la Determinación del estado Poblacional de los Pepinos de mar Isostichopus fuscus. Puerto Ayora: Comisión Técnica Pesquera de la Junta de Manejo Participativo.

Reyes-Bonilla, H., Herrero-Pérezrul, M. D., González-Romero, S., GonzálezPeralta, A., and Ramírez-Hernández, Y. (2008). Abundance of the brown sea cucumber Isostichopus fuscus at the National Park Bahía de Loreto, México. Rev. Biol. Trop. 56, 265-271.

RStudio Team, (2020). RStudio: Integrated Development Environment for $R$. Boston, MA: RStudio.

Schaefer, M. B. (1954). Some aspects of the dynamics of populations important to the management of the commercial marine fisheries. Bull. Inter Am. Trop. Tuna Comm. 1, 23-56.

Schaefer, M. B. (1957). A study of the dynamics of the fishery for yellowfin tuna in the eastern tropical Pacific Ocean. Bull. Inter Am. Trop. Tuna Comm. 2, 243-285.

Schiller, L., Alava, J. J., Grove, J., Gunther, R., and Pauly, D. (2013). A Reconstruction of Fisheries Catches for the Galápagos Islands, 1950-2010. Vancouver: Fisheries Centre.

To, A. W. L., and Shea, S. K. H. (2012). Patterns and dynamics of beche-de-mer trade in Hong Kong and mainland China. TRAFFIC Bull. 24, 65-75.

Toral-Granda, M. V. (2008). "Population Status, Fisheries and Trade of Sea Cucumbers in Latin America and the Caribbean," in Sea Cucumbers: A Global Review of Fisheries and Trade FAO Fisheries and Aquaculture. FAO Technical Paper, eds V. Toral-Granda, A. Lovatelli, and M. Vasconcellos (Rome: FAO), 213-229.

Wolff, M., Ruiz, D. J., and Taylor, M. (2012a). El Niño induced changes to the Bolivar Channel ecosystem (Galápagos): comparing model simulations with historical biomass time series. Mar. Ecol. Prog. Ser. 448:7-U28. doi: 10.3354/ meps09542

Wolff, M., Schuhbauer, A., and Castrejón, M. (2012b). A revised strategy for the monitoring and management of the Galápagos sea cucumber Isostichopus fuscus (Aspidochirotida:Stichopodidade). Rev. Biol. Trop. 60:593.

Woodby, D. A., Kruse, G. H., and Larson, R. C. (1993). “A conservative application of a surplus production model to the sea cucumber fishery in southeast Alaska," in Proceedings of the International Symposium on Management Strategies for Exploited Fish Populations, eds G. Kruse, D. M. Eggers, R. J. Marasco, C. Pautzke, and T. J. Quinn, (Anchorage: Alaska Sea Grant College Program), 191-202.

Zuur, A. F., Ieno, E. N., and Elphick, C. S. (2010). A protocol for data exploration to avoid common statistical problems. Methods Ecol. Evol. 1, 3-14. doi: 10.1111/j. 2041-210X.2009.00001.x

Conflict of Interest: The authors declare that the research was conducted in the absence of any commercial or financial relationships that could be construed as a potential conflict of interest.

Copyright (c) 2020 Ramírez-González, Moity, Andrade-Vera and Reyes. This is an open-access article distributed under the terms of the Creative Commons Attribution License (CC BY). The use, distribution or reproduction in other forums is permitted, provided the original author(s) and the copyright owner(s) are credited and that the original publication in this journal is cited, in accordance with accepted academic practice. No use, distribution or reproduction is permitted which does not comply with these terms. 